\title{
Urban Subalterns in the Arab Revolutions: Cairo and Damascus in Comparative Perspective
}

\author{
SALWA ISMAIL \\ SOAS, University of London
}

This paper examines the role of urban subalterns both as participatory agents in the Arab revolutions and as mediating forces against revolutionary action. The main argument it advances is that the positioning of urban subalterns during revolutionary periods should be understood in relation to their socio-spatial location in the complex urban political configuration. This configuration is shaped by power contests involving government, political elites, and diverse societal forces. Taking the revolutionary protest movements in Cairo and Damascus as my cases for comparison, I will examine the differentiated location of subaltern actors in each of these urban settings to draw out how their positioning in relation to state and government has shaped their engagement in the respective revolutions.

In the Egyptian case, the leading forces of the spectacular Tahrir Square protests, according to popularized accounts, were the educated, middle-class youth-the media-savvy Internet users. ${ }^{1}$ This narrative underestimates popular forces in terms of both the role they played in the Revolution and their modes of engagement with it. In contrast, this paper will explore the modes of urban popular action before and during the Tahrir days of the Revolution; it will look at confrontations between popular forces and agents of the state (especially the police), the mobilization of residents of urban popular quarters, and agitation and revolutionary action within popular quarters. My argument is that popular patterns of activism in Cairo are anchored in forms

Acknowledgments: An earlier version of this paper was presented at the Conference Urban Revolutions in the Age of Global Urbanism, held in Jakarta, Indonesia, 16-20 March 2012. I thank the conference organizers and participants for their thoughtful comments. I also thank the anonymous CSSH reviewers for their critical feedback and suggestions. The research for this paper was supported by an Economic and Social Research Council of the UK (ESRC) research fellowship (Res-000-27-0007) and by an ESRC grant (Res-062-23-2283).

${ }^{1}$ For an example of media representations of the Revolution as an event that originated in and was managed by Facebook, see Crovitz 2011. For an analysis of the Revolution as a "decidedly middle-class uprising," see Kandil 2012. 
of everyday interaction between popular forces and agents of government, which, in turn, have shaped the urban subjectivities that entered into the making of "the people" as the subject of the Revolution. Drawing on my fieldwork in Cairo's informal markets in 2010, and my earlier work with residents of informal urban quarters, I will situate the formation of oppositional subjectivities in the context of macro socio-political developments brought about by neoliberal economic policies, namely the growth of informality in housing and employment and the intensification of state security politics. ${ }^{2}$

In this account of the role of urban popular forces in the Revolution, I zero in on a particular constellation of micro-power relations and dynamics of interaction that were formative of oppositional subjectivities enacted during the revolutionary protests in Tahrir and in their aftermath. Undoubtedly, the increased level of political mobilization in the preceding decade and the accumulated experience of organized activism by various social and political actors such as workers, professionals, and youth groups are also key factors in accounting for the revolutionary activism of Tahrir. ${ }^{3}$ Thus, while my attention to the micro- and local-levels of action is intended to elucidate how popular repertoires of action and resistance are spatially grounded and territorialized, it is important to take note that the local concerns of popular forces, such as police violence, and struggles for housing rights and social services, were not isolated from the national demands espoused in Tahrir-local activism articulated with the nation-wide mobilization that began on 25 January 2011.

The Syrian case provides a counterpoint to the Egyptian one, and allows for a comparative analysis of the role of urban subaltern forces in the Arab revolutions. This comparison puts that role into sharper focus, revealing not only differing forms of organization and activism among subalterns, but also varying levels of cohesion and lines of division. Damascus presents a striking example of the fragmented nature of subalternity. Owing to the configuration of the urban space and its modes of control by the Syrian ruling regime, it was difficult for subaltern forces in Damascus to undertake the same type of mobilization and occupation of central public spaces as witnessed in Cairo. The fragmentation of subalternity in socio-spatial terms has been instrumentalized by the regime to divide subalterns and undermine the formation of a unified popular opposition.

\footnotetext{
${ }^{2}$ I undertook extended periods of fieldwork in a number of popular neighborhoods of Cairo between 1999 and the end of 2010. In the early part of this period, I worked predominately in Bulaq al-Dakrur (see Ismail 2006). In a later stage, I spent most of 2010 working in al-Moski market and al-Gammaliyya neighborhood.

${ }^{3}$ For an overview of social and political mobilization in preceding years, see El-Ghobashy 2011. See also Beinin (2012) on labor mobilization and its contribution to the "culture of protest" witnessed in the Revolution. On the youth protest groups that played an important mobilizational role, see Ezbawy 2012.
} 
The paper will focus on three features of the Damascene urban setting that help to explain patterns of mobilization and protest there: first, the fragmentation of subaltern identities where sectarian identification is an element of urban divisions; second, the inscription of apparatuses of violence in urban space in a manner that deepens divisions and manipulates sectarian identification; and third, a particular pattern of urban reconfiguration by virtue of which segments of subaltern migrant populations are positioned as buffers between the regime and other subaltern groups. These features of urban space in Damascus reveal how the history and character of urban reconfigurations can be crucial to the shape and course of popular protests and mobilizations during revolutionary periods. In Damascus, informality in housing and employment are factors of social differentiation and division among subalterns as much as between subalterns and dominant forces. My discussion here will draw on fieldwork in various urban quarters of the city prior to the revolutionary Uprising that commenced in March of 2011 and on interviews with youth activists during the Uprising. ${ }^{4}$ I will briefly sketch the reconfiguration of Damascus under the rule of the al-Asad regime, which will allow for a more nuanced examination of the differentiated subaltern subjectivities within the popular Uprising.

THE SUBALTERN, THE POPULAR, AND THE QUESTION OF

POLITICAL A GENCY

Before proceeding with my comparative analysis of Cairo and Damascus prior to and during the revolutions, a note regarding my use of the category of "urban subalterns" is in order. As will become apparent, I use the terms "subaltern forces" and "popular forces" interchangeably. In doing so, I aim to effect an analytical approximation, if not a translation. "Popular forces" is the category used in studies of the Arab Middle East to refer to diverse social actors who are distinguished primarily from the dominant social, political, and cultural elites. ${ }^{5}$ These actors, though neither homogenous nor forming a singular entity, are seen to draw on common social and cultural frames of reference and to share a degree of socio-spatial proximity, occupying city quarters conventionally referred to as "popular quarters" (al-ahyya' al-sha 'biyya). Further, Al-Sha 'b (the people) and al-Quwwa al-Sha biyya (popular forces) are the terms used in Arabic to denote non-elite but socially diverse actors. Both terms have acquired a dense and rich symbolism through a long history of use, from

\footnotetext{
${ }^{4}$ I conducted fieldwork between November 2004 and June 2005 in a number of neighborhoods in Damascus, primarily in the informal quarters of Qaboun, Barzeh, Mezza 86, Sbina, Qadam, and Dahadil. I also interviewed merchants in the markets of Hamidiyya and Hariqa, as well as residents of a number of old quarters. During a second period of extended fieldwork (between the end of November 2010 and the end of May 2011), I interviewed political dissidents and youth activists involved in organizing demonstrations and in the cultural work of the Uprising.

5 The categories of "popular forces" and "popular politics" are also widely deployed in analyses of Latin American and African politics.
} 
referring to agents of anti-colonial and emancipation struggles, to the somewhat romanticized bearers of cultural authenticity and social valor, or, with sometimes stigmatizing intent, to "the people" as an uncultured mass that is either apathetic or prone to violent outbursts. Inspired by "writing history from below" and Gramscian conceptions of counter-hegemony, among other theoretical approaches, a body of scholarly work has explored the "people's" political agency by giving attention to popular spaces, social fields of action, and informal politics (see, for example, Singerman 1995; Gelvin 1998).

Like the term "popular forces," "subaltern" has been deployed to describe social actors who are defined by their exclusion from the formal political sphere and by their marginalization, and who are considered, from both culturalist and economistic perspectives, to lack political agency. The construct of "subaltern" was developed to challenge the denial of the political agency of subordinate groups. There have been many scholarly debates on different uses and merits of the term, but I will not address these here (see O'Hanlon and Washbrook 1992; Prakash 1992; and Lal 2001). Instead, I want to elucidate the conceptual common ground between "popular forces" and "urban subalterns" for analytical purposes. "Subaltern," drawn from Gramsci's writings, was formulated by modern Indian historians seeking to recover the struggles and political contributions, omitted in colonial and elite historiography, of populations distinguished from the elite and enmeshed in relations of domination. ${ }^{6}$ In this new project of writing Indian history, the non-elites were thought of as "the people" and subalternity denoted their state/condition of subordination (Guha 1988; Spivak 2005; Roy 2011). ${ }^{7}$ I want to draw on this early conceptualization of the subaltern and to engage with more recent reflections on subaltern urbanism to enrich the analysis of urban popular forces in the Middle East, and particularly of their role in the recent revolutions. ${ }^{8}$ The same analytical questions that have been posed about "popular forces" have also been raised in relation to urban "subalterns," most importantly regarding their socio-spatial positionality, their grounds of action, and the factors that shape their political subjectivities (see Roy 2011). It is here that we can reap the benefits of analytical translation.

Ananya Roy's (2011) critical propositions on subaltern urbanism revisit conventional equations between subalternity and dispossession, and between

\footnotetext{
${ }^{6}$ For a broad consideration of the issues involved in the writing of Indian history, see Chakrabarty 1992.

7 Guha, a founding and leading figure of the Subaltern Studies collective, uses "the people" and "the subaltern" interchangeably (1988). The relation between the subaltern and the popular is subjected to a critical reexamination in a thematic 2005 issue of Postcolonial Studies, in which a number of the contributors argue against what Spivak called the slippage from subaltern to the popular (e.g., see note 9 below).

8 For an example of writings on the Middle East influenced by Subaltern Studies, see Beinin (2001) and Webber (1998). Chalcraft (2008) explores the promise of an analytical engagement with Subaltern Studies by scholars of the Middle East. See Mallon (1994) for a discussion of the influence of Subaltern Studies on Latin Americanists.
} 
informality and poverty. Roy's critique problematizes static and essentialist constructs of subalterns as fixed sociological categories pinned down in topographical and ontological terms. Challenging conceptions of informal urban spaces as "the habitus of the dispossessed," that assign a particular topography to subalterns, she points to the differentiated nature of informality that is effected through governmental administrative and regulatory practices. In agreement with Spivak (2005), Roy critiques the inscription of the subaltern in the popular, a move which, according to Spivak, assigns the subaltern an identity, and thereby ontologizes subalternity. ${ }^{9}$ But I argue that this ontologizing of the subaltern is not inevitable if we view the identity of the popular as being itself relational and contextually produced, even when popular identity finds anchor in historical cultural traditions and asserts continuity and stability. Furthermore, "the subaltern" and "the popular" are mutually inscribed categories in the sense that if subalternity is about the subordinate subject's assumption of agency, "the popular," as identity, similarly does not escape power practices and related normative and material hierarchies that cast it as subordinate. In this sense, "the popular" preserves identity as an element central to practices of domination and contestation. In fact, this identity enters into the making of the oppositional subject; that is, it is an element of political agency.

How do these theoretical propositions inform my analysis of the two cases, and how do the cases add to our understanding of the popular and the subaltern? In approaching urban popular forces as subalterns, I hope to capture the relational character of their subordination. In Cairo, it is in interactions with government and the police, within the context of a conjunction of neoliberal and security politics, that popular forces' subordination is effected and their assumption of oppositional subjectivities takes place. In this respect, I do not propose to see popular quarters as the habitation of the dispossessed, or informality as an ontological state. Roy's remarks on informality as being the

\footnotetext{
${ }^{9}$ Spivak (2005) defines the subaltern as "a position without identity," a premise upon which she bases her rejection of the slippage from "subaltern" to "popular" and her critique of the analytical use of "the people" as an instance of "an abstract posing as the concrete." There is a programmatic element to Spivak's formulations: proceeding from an insistence on the singularity of subaltern action and the unrecognizable character of subaltern agency, she proposes an understanding of collective agency as that of having the part that agrees stand for the whole, a move that she conceives of as conditional on the putting aside of difference (i.e., suspending identity). Spivak seems to be positing identity (and at some point in her analysis culture as well) as an essentializing claim to difference that, by definition, possesses a reactionary potential; she protests that "identity slides into culture," which in turn is "often indistinguishable from religion." It is unclear why identity claims and identity-making practices should negate subalternity as a condition and relation, and why these should be, by definition, reactionary. This raises the question of the basis on which the definition of subalternity, as proposed by Spivak, should be limited to a certain kind of politics - "emancipatory" - to the exclusion of others - "identitarian" or "nationalist." Spivak's propositions on "identity," "culture," and "religion" are made in a sweeping fashion more in the order of polemics than of analytic diagnostics.
} 
effect of power relations ring true when we look at the differentiated positioning of informal quarters of Damascus vis-à-vis the Uprising, where occupying informal space does not necessarily translate into opposition to the regime. In reality, it is within the informal production of space that divisions among subaltern populations are produced. Finally, in inscribing the subaltern in the popular, I am interested in thinking out the grounds of political agency in relation to the subjectivities that arise from popular forces' interactions with government. Rather than proceeding from a priori assumptions about subalterns' political agency, I will tease out the complex factors that shape subalterns' positioning within the web of power and control.

POPULAR FORCES AND SPATIALIZED RESISTANCE

IN THE EGYPTIAN REVOLUTION

Popular mobilization and activism has sustained and continues to consolidate the unfolding Revolution in Egypt. The role played by the popular forces can only be fully understood in relation to their position in the urban configuration, forms of community organization, modes of activism, social and symbolic capital, and above all their patterns of interaction with government. All of these factors have shaped their engagement in the protests and their actions against the regime and its main institution of government, namely the police. At the same time, popular forces' repertoires of activism and territorialized resistance articulate with broader political projects. What is more, local mobilization and actions are informed by Tahrir-centered activism. To trace the contours of subaltern participation and the forms it has taken, I begin with a brief sketch of the place of popular quarters in the urban setting. I will tease out key features, most importantly informality in economic activities and housing, which afforded these forces a degree of autonomy in their social organization while in turn informing their antagonistic relations with government. In the second subsection, I examine the character and nature of popular participation to highlight how certain dynamics of the urban form and the antagonisms inscribed in it have been manifested in the Revolution.

\section{Popular Cairo: Informality and Roots of Dissidence}

Here I will summarize aspects of how Cairo has been reconfigured since the 1970s, particularly through the emergence of new popular quarters as spaces of relative autonomy, dissidence, and contestation against government. Much of this urban expansion took place informally and independent of state planning. Ordinary people established residential quarters by either squatting on state land or building on agricultural land, in both cases violating official regulations governing construction. Many old popular quarters were sites of informal expansion. This dimension of urban reconfiguration should be viewed against the background of the state's retreat from its role of welfare provider and the implementation of neoliberal economic policies that were first 
instituted in the $1980 \mathrm{~s}$ and took fully developed form in the $1990 \mathrm{~s} .{ }^{10}$ The growth in informal employment and the increased privatization of social services were factors of popular forces' disengagement from the state and their attainment of a degree of autonomy. This autonomy was manifested in the establishment of community-based institutions and mechanisms of dispute management, the local enforcement of social norms of interaction, and social support networks (Ismail 2006). In an attempt to contain this growing social and economic autonomy, the state intensified security politics by expanding police monitoring and surveillance practices in popular areas.

The history of new-quarters establishment, alongside other factors such as the prevalence of informal economic activities in them, gave rise to a conflictual relationship with the government when state agents and agencies tried to impose control in the quarters in the name of law and order. Interaction with these agents and agencies, particularly with the police, has been a structuring element of the everyday life of the residents of both the informal quarters and the city's old established districts. Police carried out regular and diverse campaigns in popular neighborhoods with the goal of imposing control of space and managing the population's conduct and activities. Accounts of encounters with the police reveal the development of a particular structure of feelings, to which humiliation is central (see Ismail 2006; 2012). Often, such episodes involve police campaigns in markets and seizures of goods and vending scales. These regular occurrences bear similarities to the market incident that led Mohammad Bouazizi in Tunisia to commit his extraordinary act of self-immolation: officers slapping, beating, and shoving vendors and forcefully seizing scales that are indispensable to earning a living in the market. Such experiences contribute to the making of an oppositional subject who may act alone or in concert with others at a given moment.

\section{Urban Subalterns in the Battle for Cairo}

In the romanticized images of the Revolution, Tahrir protests are a model of civil resistance-peaceful, "cultured," and egalitarian. In such depictions, the main actors are the middle classes, led and inspired by the educated youth. Excluded from this narrative are the popular forces, especially the inhabitants of the city's informal neighborhoods. ${ }^{11}$ Also edited out are many of the scenes

${ }^{10}$ Welfare provision covered free education, public health insurance, and subsidized foodstuffs. In the 1950s and 1960s, it also included publicly funded low-income housing projects known as "popular housing" (masakin sha 'biyya). With economic liberalization, public housing came to constitute a negligible portion of the market, while both public education and health services underwent a process of masked privatization. Most subsidies on basic foodstuffs were removed.

11 For example, a leftist Egyptian analyst commented in reference to the participation in the protests of the urban poor, who he identified as "the shanty town dwellers," that "fortunately this menacing human mass was entirely absent from the revolt, which probably contributed to its civilized and peaceful character" (see Kandil 2011, my emphasis). 
of violence in the back streets of Tahrir and the popular quarters, including the burning down of police stations - reportedly ninety-nine of them across the country. ${ }^{12}$ The assaults on police stations took place primarily in densely populated areas long stigmatized in official public discourse for being part of the city's " "ashwa'iyyat" (literally "haphazard communities") such as Bulaq al-Dakrur, Matariyya, and Imbaba, and in old popular quarters such as Bab al-Shi'riyya and Gammaliyya. In these areas protesters stormed and torched police buildings and set armored cars afire. I contend that, for these protestors, the Revolution was a revolution against the police (see Ismail 2012). The police stations were the sites of violent government through torture, verbal abuse, and humiliation, while police officers have long served as agents of everyday government in the popular quarters.

These attacks aimed to both settle accounts with the police and disarm them so that the protests could continue. For example, it is reported that in the old neighborhood of Sayyida Zaynab ten thousand residents marched to the district police station when the central security forces tried to block a procession to Tahrir and began firing on demonstrators. The station was burned after police shot and killed several protestors. This was followed by attacks on other stations in al-Azbakiyya, Ayn Shams, al-Sahil, and Bassatin, among others, in what some press reports described as a surge of popular demonstrations for the control and neutralization of the stations (see al-Youm al-Sabi', 30 Jan. 2012). The centrality to the Revolution of the quarter-based confrontations with the police was asserted by Gamal Bashir, a youth activist and former member of the White Knights Ultras, the fan club of the Zamalik Football team. In a critical commentary on those narratives that represented the Revolution as a peaceful affair of middle-class youth protests in Tahrir, he stated: "Let's not forget what happened in the days between 25 January and 28 January, this glossed-over part of history.... There were constant clashes in Omraneya for example, and there were people in Talbiya trying to get to the Foreign Ministry. The fighting continued long after the political elite were tear-gassed out of the square on 25 January." He adds, "[t]he power of this revolution came from these harafish [a term used to denote the "rabble" and valorized in the writing of Egyptian novelist Naguib Mahfouz] burning police stations and from the collapse of the Interior Ministry. That was utilized by the political elites who centralized the struggle in Tahrir

12 For accounts of assaults on police stations, see al-Masry al-Youm, 30 Jan. 2011; al-Youm al-Sabi', 30 Jan. 2011; and al-Ahram, 10 Feb. 2011. Based on a survey of press reports and publications of the General Organization for Information (al-Hay'at al-'Ama li-Isti'lamat), it is possible to ascertain that twenty-five police stations were burned in popular quarters of Greater Cairo between 25 and 28 January 2011 alone. The quarters were: Sayyida Zaynab, Azbakiyya, Ayn Shams, al-Sahil, al-Bassatin, Dar al-Salam, Helwan, Giza, al-Warraq, al-Talbiyya, al-Umraniyya, Imbaba, Bulaq al-Dakrur, al-Gammaliyya, Bab al-Shi'riyya, Al-Amiriyya, al-Wayli, al-Marj, al-Sharrabiya, al-Zawwiyya, al-Zaytun, al-Salam Awal, al-Matariyya, al-Nahda, and Kirdasa. 
Square. Without this confrontation, the revolution wouldn't have been possible and every police station was burned to the ground because people have been dying inside them for years" (cited in Hussein 2012).

Since Mubarak's resignation, the attacks on police stations have been subject to much debate. While the Ministry of the Interior and some segments of the mainstream media have portrayed them as the work of thugs (baltagiyya), vandals, and criminals, prominent activists have stressed that the policestation burnings were an organic act of the Revolution. ${ }^{13}$ The official narratives deny moral recognition of the contribution of popular-class youth to the Revolution. In a telling development, courts considering cases brought against police officers accused of shooting protestors in popular neighborhoods have issued verdicts clearing the officers of wrongdoing. According to summaries of these deliberations, the courts took the view that the assaults were carried out by vandals and infiltrators and do not fall within the frame of the events of the Revolution (see Izzat 2012). Popular-youth actors who died at the hands of the police in popular neighborhoods were thus denied the status of revolutionaries and martyrs, leaving their families with little opportunity to claim compensation let alone moral recognition for the deaths of their sons and daughters. These court decisions and public debates epitomize contests over the role of popular forces in the Revolution and the character of their participation.

My account of popular quarters' engagement in the Revolution is intended to convey the importance of the spaces of resistance and stress that the clashes with the security forces were spatially grounded and expressed the antagonisms inscribed in the spaces of popular quarters. ${ }^{14}$ My argument here is that popular forces' participation in the Revolution, as observed in these quarter-based confrontations, illuminates the territorialized and localized dimensions of resistance. Further, while these battles were integral to the Revolution, they were also resumptions of unresolved conflicts with agents and agencies of government. In this way, local concerns and experiences articulated with the national project of transformation espoused during the mass mobilization in Tahrir.

${ }^{13}$ For example, Nawara Nijm, a spokesperson of the revolutionary youth in Tahrir, stated that the burning of the stations was an act of revolution, not thuggery (Al-Wafd, 20 Mar. 2012). For a discussion of the contests surrounding the use of baltagiyya under the Mubarak regime, see Ismail 2006. For an engaged rebuttal of the stigmatization by mainstream media of the actions of popular-class youth against the police during the Tahrir days, see Izzat 2012. Izzat asserts that the Revolution would not have succeeded without "breaking the security arm of the Mubarak regime," reminding, "[t]he police was the number one enemy of the Egyptian people under the rule of Mubarak." In a similar vein, Mohamed Abo El-Gheit challenges the dominant narratives of the protests as being led by the April Six movement or the Muslim Brotherhood, asserting that popular-class youth protected the marches and were instrumental in chasing away the security forces (2011). I thank an anonymous CSSH reviewer for drawing my attention to Abo El-Gheit's blog.

${ }^{14}$ I draw on Ismail 2012 for the account of the quarter battles with the police. 
Quarter-based participation in the Revolution took the shape of street battles in which stones and Molotov cocktails were occasionally used against the security forces' live bullets. The clashes with the police and attacks on their stations pushed them back and undermined their ability to stop protest processions from going on to Tahrir Square. This is well illustrated by the battles that took place in Old City quarters, as in the area known as Fatimid Cairo, and in the Bulaq Abul al-Ila quarter, which, by virtue of its proximity to Tahrir Square, became the back streets of the confrontation with the police. In what follows, I look at these and other quarters that participated in the fights with the police, and outline the conflictual relations between them and the government and the nature of the spatially grounded hostility. My attention to local action is consonant with Arturo Escobar's (2001) argument that place-based struggles can be understood as "subaltern strategies of localization." It is such strategies that laid the groundwork for the popular forces' engagement in the Revolution.

The battle of Fatimid Cairo, which took place in the old quarter of Gammaliyya and the popular market of al-Moski, is a clear example of popular forces' locally inscribed participation in the Revolution. The battle was fought between the people and the police in the first few days of the Revolution on the main thoroughfares and in al-Moski alleyways. To understand it we must grasp the topography of the area that was marked by the residents and merchants' daily encounters and antagonistic relations with the police. This antagonism arose in conjunction with police campaigns on the market, which included routine confiscations of goods. Because the area attracts many tourists, it is subjected to added security surveillance, and workers from the area's shops and workshops were often targeted by police practices of ishtibah wa tahari (stop and investigation) (Ismail 2012). In this setting, the quarterbased street battles connected with ongoing struggles against government practices that undermined the area's livelihood. As in other quarters, local concerns and experiences of government, with their local inflections, motivated the area's activism and participation in the revolutionary protests.

Popular forces within the quarters are neither uniform nor homogeneous in character and are differentiated by their positions within the local social structure. This differentiation arises out of modes of insertion into the national and global economies and highlights the dynamics of socio-economic transformation of the popular strata. For example, with the liberalization of trade, new layers of merchants and traders emerged with opportunities created by the import of consumer items from China. In this process, kiosk vendors and peddlers became able to compete with established merchants and undercut the trade of some. This brought about an increase in competition and had a detrimental effect on local workshop production. In assessing these transformations of the popular market, one merchant of a middle-sized enterprise whom I interviewed asserted that "heads were leveled" (al rus itsawit), meaning that the 
small street vendors, seizing the niches created by the opportunity to import cheap goods from China, are challenging the area's middle-sized and possibly large-scale merchants. This "equalization" has occasioned frictions among shop-owners and street vendors, which at times has led to fights and police interventions.

Notwithstanding the hierarchies of the informal market, merchants and vendors in popular markets such as that of al-Moski found themselves at a competitive disadvantage in relation to large businessmen connected with the regime and ruling elites. The latter were viewed as influencing trade and customs regulations to squeeze traders out of informal markets. This appeared to be the case with the 2010 introduction of a requirement of "quality certificates" for Chinese goods and a ban on mobile phone imports from China. These regulations negatively affected both established merchants and newer, small-scale vendors since all are bound together by informal credit and finance arrangements and networks of supply and circulation, which are often organized on the basis of kin relations and regional origin. Though merchants and vendors may be differentiated in economic terms on the basis of the size of their enterprises and accumulated capital, they may nonetheless find common ground for opposition to the regime and state agents based on market arrangements, socio-spatial proximity, and shared grievances against policies that favor business-elites. As such, it can be argued that a structure of collective subjectivity grounded the collective action of differentiated urban subalterns.

As in Gammaliyya, Bulaq Abul al-Ila - an old popular quarter close to Tahrir Square-facilitated the movement of protestors and provided them safe passage on the way to Tahrir. On 27 January, Abu al-Ila residents faced off against central security forces to prevent their entry into the area (I draw here on Ismail 2012). The defense of place manifested in the street battles is linked with ongoing struggles to preserve the quarter and local life against joint state-global capital designs on the neighborhood's valued real estate. In the first days of the Revolution, protesters there raised local concerns and demanded social and economic rights. Subsequently, their demands meshed with the political project of Tahrir aimed at the removal of the regime. ${ }^{15}$ Bulaq Abu al-Ila's conflictual relations with the government and the police revolved around struggles for housing rights and the maintenance of community autonomy through forms of internal governance.

Located in central Cairo, the quarter has been the object of successive public and private designs of "urban renewal" (on earlier phases of these, see Ghannam 2002). In the latest phase, multinational real estate companies and large urban developers have maneuvered to gain possession of empty lots as

\footnotetext{
15 It should be noted that one of the key slogans of Tahrir is the socially and politically inclusive " 'aysh, hurriyya, "adala igtima iyya" (bread, freedom, social justice).
} 
well as dilapidated old buildings. The real estate investors' plans were to turn various sections of Bulaq Abu al-Ila into expensive residential and commercial centers. Meanwhile, under the Cairo 2050 Plan - conceived as a proposal to transform Cairo into a "global capital"- the Cairo governorate announced its intention to repossess residential buildings and shops. In line with this plan, in the few years preceding the Revolution the police forcibly evicted some quarter residents after their homes collapsed. Administrative and coercive practices were, in effect, used to turn areas of Abu al-Ila into slums to pave the way for eviction and demolition. In joining the revolutionary protests, Bulaq Abu al-Ila residents' goals included the defense of the right to housing and healthy living conditions (see Luccini and Morandini 2011). The conflict between global capitalism and the inhabitants has intensified over the last year, indicating that the concerns of popular quarters remain central to the unfolding Revolution. ${ }^{16}$

There were other conflicts with government as well, relating to public order interventions by the police. Abu al-Ila, like other popular quarters of the city, had established forms of internal governance such as majalis 'urfiyya (customary councils) to regulate disputes and to eschew police intervention. On occasions when these institutions faltered and conflicting parties resorted to violence, police found a pretext to enter an area and attempt to establish control and a more visible and immediate presence. The police also pursued practices of cooptation and indirect control through pro-regime local notables, members of the People's Assembly, and heads of municipalities. Often these entities overlapped. For example, one of the quarter's members of Parliament was a former general in the State Security Department who enjoyed the support of former Minister of the Interior Habib al-Adli (see al-Masry al-Youm, 19 Oct. 2010). Other figures of authority and mediation were proprietors of large-scale enterprises who were members of the nowdissolved National Democratic Party (interview with steel trader in Bulaq Abu al-Ila, Apr. 2010). These political and economic contests played out in the national elections in the quarter and in the struggles over control of the area's real estate and diverse trades. These were emblematic of the aforementioned conjunction of police government and economic interests promoted by neoliberal policies.

The articulation of locally inscribed antagonism with the national protests and Tahrir-centered activism evident in Fatimid Cairo and in Bulaq Abu al-Ila could also be observed in new popular quarters. In quarters such as Bulaq al-Dakrur, Umraniyya, and Imbaba, some residents stormed and burned the

\footnotetext{
${ }^{16}$ In one part of the district of Bulaq Abu al-Ila, namely Ramlat Bulaq, the residents' resistance against eviction attempts by the state, in conjunction with private investors, most notably global telecommunications tycoon Naguib Sawiris, has taken a violent turn in recent months (see Elshahed 2012).
} 
police stations, and on 25 January 2011 residents of these quarters organized marches to Tahrir, thereby lending vital support to national mobilization on that day. The youth activists who called for the Police Day protest on Facebook worked with the residents of Bulaq al-Dakrur to plan a procession on 25 January from Nahya Street, one of the quarter's thoroughfares (interview with Khaled Abd al-Hamid, a key coordinator of the 25 January protests, Cairo, 2 Mar. 2011). ${ }^{17}$ The mobilization in the quarter was successful and some fifteen hundred people - of some three thousand who marched out of the quarter-made it to Tahrir Square (drawn from Ismail 2012). While Bulaq al-Dakrur residents coordinated with youth organizers in Tahrir, in nearby quarters such as Faysal processions were organized by local residents themselves. Indeed, the experience of confrontation with the police and the strength of hostility toward government among residents of quarters like Bulaq al-Dakrur made them ideal spaces of mobilization during the Revolution's early days. In their everyday encounters with the police, popular forces honed a multitude of practices that ranged from evasion to confrontation (see Ismail 2006). These practices of everyday life laid down a pattern of relations and repertoires of action that were played out in the clashes with the police during the Revolution.

Important here is the role that the members of the Ultras football team fan groups played in the organization of marches to Tahrir. These youths, who belong to neighborhood-based sections of the Ultras groups, led processions from Haram, Faysal, and other popular neighborhoods. According to activists, the Ultras, already experienced in countering police tactics of crowd control, identified the weak points in security police lines and maneuvered to break them (interview with Ahly Ultras activists, Cairo, May 2012). The marches from popular quarters bear the marks of coordinated action not only because core Tahrir Square protest leaders and activists mobilized on the ground in Bulaq al-Dakrur, but also because Ultras youth from popular quarters discussed the Facebook call for "a day of anger" and debated whether to participate as Ultras or as individuals. They opted, first, to join quarter processions on an individual basis and then, on 28 January, decided to participate under the Ultras banners (ibid.).

Youth from popular quarters engaged in the protests informed by their relations with the police, especially having been the primary targets of disciplinary practices such as ishtibah wa tahari. In the early 1980s, youth opposition was primarily expressed through activism in militant Islamist groups (Ismail 2000). By the early 1990s, quietist religious groups and neighborhood fraternities had supplanted the radical groups and became the basis for a strongly territorialized youth identity invested in the quarter spaces such as

${ }^{17}$ For a similar account, see Levinson and Coker 2011. 
alleyways, workshops, and informal markets. To the extent that this identity is produced within relations of power, "the popular" as identity is inscribed in "the subaltern" as positionality. Furthermore, this identity enters into the making of political agency. For example, in my interviews with youths about their relations with the police, they denounced their subjectivation by the police. They also expressly noted contradictions and tensions between their self-identities of "ibn al balad" (son of the country) or "sannayy 'i hur" (free worker) and their subjection to police practices of humiliation (Ismail 2006; interviews with youth activists, Cairo, Feb. 2011 and May 2012). Rami, an Ahly Ultras activist who led a procession from Haram on 25 January, reflected on the clashes with the police on the street and in the stadium: "It is a way of saying [to the police] I have broken you. You sold the country; you are not respectable. You humiliated me and belittled my dignity. You made me take off my clothes when entering the stadium. This is how you treat us. I will answer you from your own perspective and your culture. This expresses a condition (hala).... I was beaten; I experienced humiliation. For twenty-five years, I was a non-participant" (interview, Cairo, May 2012). ${ }^{18}$

This account of the mobilization of popular forces and their participation in the Revolution emphasizes that the infrastructures of protest lay in the microprocesses of everyday life that developed at the quarter level, in community forms of organization and in popular youth's modes of action and interaction with state government. The political agency of subaltern forces is not merely reactive; it does not, as Bayat (2000) suggests, arise only when threatened by government action. Such a reading of subaltern agency downplays the terms in which everyday forms of organization and modes of governance and positioning vis-à-vis government furnish mobilizational resources, and generate shared understandings and feelings that constitute the oppositional subject who may act individually or in concert with others even when there is no threat to their immediate interests. Youth fraternities (neighborhood-based and street-centered everyday sociability circles organized around work and home), charitable organizations, and neighborhood-based provision of security not only allowed for a degree of disengagement from state government, but also were frames of collective modes of everyday life. In other words, far from living an atomized life or pursuing their means of living individually, popular forces built community institutions, and fought over and negotiated normative rules. Additionally, a political know-how, derived from the daily experience of government, guided the participation of youth from popular

\footnotetext{
18 The Ultras and youth from popular quarters have continued to mobilize against the police and the Ministry of the Interior, as witnessed in the battles of Mohammad Mahmoud Street and Mansour Street in central Cairo, notably in September and November of 2011, and in February 2012 in response to the Port Said massacre in which Ahly Ultras fans were killed. It is alleged that rival fans from the Port Said club murdered them, and it is suspected that they did so with police complicity.
} 
quarters. Bashir's distinction noted earlier, between elite politics and popularclasses politics, resonates with Rami's account, during the interview just quoted from, of how Ultras activism and symbolic work fed into the Revolution: "Everything we did is politics; the slogans and chants. We practice politics using our language, the language of the people organized in the public square. The slogans we shouted during the Revolution protests, we had shouted before. In fights with the police we had chanted 'ah ya dawlat al-haramiyya, hiyya klabik al-dakhliyya' (Oh state of thieves, the Interior Ministry are your dogs). After the 2010 elections we had chants like 'ihna shababik ya hurriyya' (Oh freedom, we are your youth)."

The participation of popular forces in the Egyptian Revolution may appear primarily contingent when understood only as part of a seemingly spontaneous movement of mass mobilization and peaceful insurrection against the ruling regime. Additionally, because they lack formal social movement organizations, popular forces tend to be seen as followers, of either the organized Islamist opposition or the middle-class activists who agitated for the national protests that made up the first phase of the Revolution. However, this manner of framing popular forces' engagement and activism during and after the Tahrir days does not capture factors that are crucial to explaining the massive participation of Cairo's subaltern forces. From my sketch of quarter-based mobilization and action we can glean three factors that have shaped the rising up of subalterns against the regime: one, a degree of autonomy and disengagement from the state that was achieved through informal economic and social arrangements; two, the development of locally based internal forms of governance that managed security needs and disputes, and enforced norms of interaction; and three, oppositional positioning from state government and a long history of conflictual interaction with state agents and agencies.

The popular forces, the youth, and the middle classes coalesced as "the people" on 25 January 2011. Al sha 'b as the collective subject of the Revolution was formed in the coming together of social forces and individuals unified by their rejection of a particular mode of government. These oppositional subjects are not only collectivities organized in pursuit of specific goals; but are also collections of individual subjects fashioned in interactions with agents of the state. These subjectivities were formed among the popular forces and in the spaces of the city's popular quarters. These forces enacted their oppositional subjectivities side by side with the visibly organized political opposition in Tahrir (Ismail 2012).

\section{DIFFERENTIATED URBAN SUBALTERNITY IN SYRIA}

The Syrian Uprising has seen massive and sustained mobilization in a number of Syrian cities, notably in Homs and Hama and in Damascus, where most of the protest has taken place in the peripheral quarters and suburbs and in the adjacent towns of the governorate of rural Damascus. At the same time, until 
recently, there was a noticeable quietism in other cities, particularly Aleppo. ${ }^{19}$ The latter's reticence to join the Uprising and the relative quiet of central Damascus have been interpreted as evidence of support for the regime in the country's two major cities. I want to address the particular geographical distribution of the Uprising, focusing in particular on events in Damascus. Specifically, I will consider the question of how differentiated urban subalternity has given rise to divisions among subaltern forces, with some segments supporting the regime against the Uprising. In my examination of this question, I contend that the particularities of the urban form and the socio-spatial divisions traversing it are the main variables at work in creating and sustaining these divisions.

\section{Damascus in the Syrian Uprising}

The Uprising began in Dar'a, a city in the southern governorate of Dar'a on the border with Jordan. ${ }^{20}$ The immediate spark was the detention and reported torture of school children who wrote on their school wall the slogan of revolutions elsewhere: "The people want to bring down the regime." There were also local grievances in Dar'a having to do with land issues, construction permits, and the like. In response to the violent suppression of the Dar'a demonstrations, protests were held in other cities and towns, which gave rise to further crackdowns by the state, followed by a cycle of protests and violent suppression. In my interviews with activists from various quarters of Damascus and other parts of Syria, they confirmed that the mobilization in the early days of the Uprising was not a response to calls on Facebook, beginning in late January 2011, for a Syrian "day of anger," but rather a spontaneous action intended to express solidarity for Dar'a. ${ }^{21}$ Douma, a Damascus suburb, was one place that rose in support of Dar'a early on. Thus very soon after the events in Dar'a anti-government protest was taking place near the capital. In various localities and regions, local concerns articulated with national aspirations and objectives, and the initial, localized character of the protest movement increasingly acquired a national-level orientation and structure through the establishment of the Syrian Local Coordinating Committees (SLLC) and the Syrian Revolution Coordination Union (SRCU).

19 The militarization of the Uprising in recent months has drawn Aleppo into it, and many parts of the city have turned into virtual battlegrounds.

${ }^{20}$ For an account of protest mobilization during the first six months of the Uprising, see Ismail 2011.

21 As the security forces responded with violence and protests grew and became focused on the objective of overthrowing the regime, local coordinating committees were established. These committees used Facebook pages to communicate information about protests. Soon this locally based activity was coordinated across neighborhoods and constituted a space for activism by youth of diverse social and religious backgrounds. Secular and Salafi activists met in detention centers where they exchanged contacts and expanded their networks and coordinated activities (personal interviews with youth activists in Damascus between March and May of 2011; and personal e-mailing with activists in Damascus, Homs, and Baniyas between October and December of 2011). 
What place does Damascus occupy in the Uprising? Despite the apparent calm, the city has seen widespread activism in three types of urban spaces: traditional quarters such as Midan and Rukn al-Din; informal quarters/suburbs such as Barzeh, Qaboun, Harasta, and Douma (the latter falls administratively within the Rural Damascus governorate); and towns in the governorate of rural Damascus such as Darayya and Mu'adhamiyya. ${ }^{22}$ How do we explain this configuration? Why has protest not spread to all of Damascus, and what role do socio-spatial variables play in this patterning of protest?

\section{Elements of Urban Division: Subalternity in Informal Quarters}

State practices of cooptation, incorporation, and exclusion are operative in the reproduction of societal forces and their constitution of political agency. The re-composition and realignment of social forces brought about by the ruling $\mathrm{Ba}$ 'th Party's populist policies at various phases of its rule must be considered. Though developmentalist phases targeted rural areas, the investment was uneven and not necessarily productive. Governorates that did not fit into the grand design of capitalized agricultural production - the governorate of Latakiyya, for example - saw the inhabitants of entire villages migrate to cities, primarily Damascus. For many households, volunteering for the army was the only avenue of employment. This was the case for Alawis and members of poorer populations of the Syrian Peninsula (the northeastern region of the country). This pattern of recruitment into the army provided nodal connections between the regime and disadvantaged sectors of the population, while, also, inscribing societal lines of division between agents of state violence and control (e.g., the army) and other social groups with whom they in fact share common socio-economic positions. Loyalty to the regime and to the president must be understood in terms of these patterns of populist cooptation and their spatial grounding.

If we turn to consider the patterns of rural-urban settlement-with rural populations being the Ba'th Party's historical base and the regime's nodal connection and point of relay-we get a clearer picture of how traditional societal divisions were recast in identitarian terms, fracturing the social body into "us" and "them" camps. To understand the reconfiguration of urban space and the realignment of social forces that capture the dynamics of conflict and division that, in turn, shape the formation of subjectivities and the positioning of subjects vis-à-vis the state, it is important to look at how the developmentalist and populist politics have marked the urban form, in particular, in Damascus, the seat of governmental power (see Hinnebusch 1990).

\footnotetext{
${ }^{22}$ With the increased militarization of the Uprising, these quarters and suburbs became sites of refuge and activities of armed groups under the umbrella of the Free Syrian Army. As a result, over the last few months, they have been targets of heavy shelling and military incursions by Syrian forces loyal to the regime.
} 
Damascus is divided along social, economic, cultural, and religious lines. Historically a mercantile city, its population was predominately Sunni but with a sizeable Christian minority. Until the late-colonial period, much of the city's political life centered round its old quarters, which were organized along socioreligious lines (see Khoury 1984). The expansion of the city brought greater social and demographic differentiation with the emergence of informal quarters and the movement of many old-quarter residents to rural Damascus. This expansion was, in part, a response to large-scale rural migration into the city from other governorates such as Idlib (predominately Sunni) and the coastal areas (primarily Alawi), which began in the 1960s and intensified in the 1970s and 1980s.

These new quarters represent a form of urban settlement based on regional origin and sect membership, as well as their links to the military and the state. A segment of the migration was tied to the military and its rise to power. Army soldiers, volunteers, and conscripts were settled in the city's periphery. This pattern of settlement was tied to inhabitants' relations with the regime. Thus, the quarter of Mezza 86, built into the rocky terrain of Mezza Mountain, emerged in the mid-1970s for the purpose of settling the members of Rif at al-Asad's "86 Division." Its inhabitants were low-level army volunteers (saf dabit), below officer rank. Mezza 86 residents are 85 percent Alawi. The history of the quarter's establishment exemplifies a pattern of incorporation into the regime through the organs of coercion. Nonetheless, the residents' urban integration or lack thereof reveals how societal divisions are maintained and manipulated. The terms of insertion of migrants into the city-economically, socially, and culturally-betray exclusion and marginalization. In my work on the urban economy of Damascus, I found that "traditional" economic activities of commerce and artisanal production remain primarily in the hands of Sunni merchants and have not integrated the newcomers except as menial workers. In Mezza 86, the first generation of migrants found work in the army but the new generation has been engaged mostly in marginal economic activity.

Like Mezza 86, Qaboun is an informal quarter built on agricultural land. It attracted migrants from northern Syria (especially rural Idlib) and rural Damascus, many of them military conscripts, and its residents found work on the margins of the local economy. Some took up smuggling in the late 1970s and early 1980s when conscripts who served in Lebanon smuggled in goods such as clothes, electrical goods, and automobile parts. Other residents branched into the service industries as minivan owners and operators. Like residents of Mezza 86, those of Qaboun have not been integrated into the Damascene economy, but they differ in that they do not depend on the regime for employment and thus have maintained a degree of autonomy from it.

The main distinction between the two quarters has to do with social and political proximity to the regime. Mezza 86 was coopted by it at the time of 
settlement and was constructed as an appendage to the ruling group. The dynamics of relations between Mezza 86 and the regime help explain the sense of precariousness that the residents felt at the time of Hafez al-Asad's death in 2000. It is said that some prepared to leave the city and return to their villages of origin as they grew increasingly uncertain about their future and fearful they would face retribution for having been loyalists. During the current Uprising, Mezza 86 has maintained the loyalist line, while Qaboun has risen up against the regime.

In the narrative history of Mezza 86-from the allocation of space or permission to squat to the provision of infrastructure services - the quarter is portrayed as an appendage of the rulers. Older residents of the quarter whom I interviewed in 2005 often ended their reflections with the words: "Life is good, we thank the president," or "May God protect the president." There is more to such statements than being versed in the cult of the leader, for they are also acknowledgement of clientelist relations that call for gratitude, which is expressed in terms euphemizing relations of subordination.

Relations with the regime and the demographic composition of quarters are the main variables at play in the differentiated responses to the Uprising observed in Damascus and elsewhere. In this complex urban configuration are found conflicts over title to land and position in relation to government, conflicts inflected with sectarian meanings. These divisions are well illustrated by the case of the Barzeh quarter on the northern edge of Damascus and its relationship with the neighboring community of 'Ish al-Warwar. The Barzeh quarter is built on agricultural land, and maintains a nucleus of its original inhabitants in the area known as Barzeh al-Balad. These long-time inhabitants are referred to as Barzawi to denote their territorialized identity. Barzeh's expansion and urban build-up began in the 1970s with the state expropriation of land for the middle-class residential project of Masakin Barzeh (Barzeh housing). Land was expropriated for the purpose of erecting military facilities, including a military hospital. The breakup of Barzeh land and the inscription of antagonisms towards the regime deepened when the families of a military unit of Rif'at al-Asad's brigades were settled on land in a rocky area called 'Ish al-Warwar adjacent to Barzeh al-Balad. The area was considered part of the communal territory of the original Barzeh inhabitants, and the settlement caused tensions from the start. It sparked an early incident of violence that is now referred to as ahdath Barzeh (the events of Barzeh). In 1975, according to my informants, the new neighbors from the 'Ish attacked a coffee shop where community elders had gathered to allot access to wells for irrigating fields. A fight broke out and some Barzeh al-Balad elders were killed. As the 'Ish was considered to be under Rif'at al-Asad's protection, the Barzeh residents believed there was little they could do to get redress, and some, fearing retribution for their role in the fight, fled. 
In the current Uprising, Barzawis and 'Ish al-Warwar inhabitants have come into conflict again. Based on accounts from a number of informants, the conflict is caused by 'Ish al-Warwar residents attacking and trying to suppress demonstrations. In the early days of the Uprising the 'Ish al-Warwar residents were told that the Barzawis were planning to attack them to regain their land. Warnings of this type are believed to be part of a regime strategy in various parts of the country to sow seeds of sectarian conflict, and I will return to this presently. 'Ish al-Warwar residents were thus mobilized against their neighbors. Two of my Barzeh interviewees portrayed low-level army recruits of the 'Ish as having more in common with their downtrodden Barzeh neighbors than with the regime they were defending. In this face-off, two subaltern groups lined up against each other. In the words of one Barzeh activist: "the 'Ish people are oppressed like us, and they are treated as slaves, but they defend the regime because they are made to fear their 'extremist' Sunni neighbors" (interview, May 2011).

Mezza 86 and 'Ish al-Warwar may represent the extreme form of clientalization through employment, bureaucratic favors, and residential arrangements, but they also exemplify the spatial and demographic patterns of change associated with the militarization of rule and of society. Entire quarters were established on the periphery of the city to house army personnel and their families, while in other quarters, particular sections or areas are identified with the military. In Qaboun, the residential buildings next to the military barracks were reserved for families of military personnel, most if not all of whom were Alawi. When I conducted interviews in the area in 2005, these buildings were often pointed out to me as places reserved for Alawis only.

The Barzeh and 'Ish al-Warwar alignment juxtaposes two poor quarters, one built in the service of the regime on expropriated land claimed by the other. This inscribes division and conflict on the basis of clientelization and exclusion, which, by virtue of the differing religious affiliations of each quarter, acquire a confessional inflection. Similar patterns of residential arrangements can be found in other quarters and neighborhoods around Damascus. The establishment of residential quarters of army families and security services provides the regime with buffer zones within urban spaces and divides the population. The urban and spatial arrangements and their demographic characteristics are one dimension of the social differentiation expressed in identitarian terms. The elements of urban divisions I have sketched here offer a glimpse of the dynamics of how the population has been ensnared, through cooptation and marginalization, in the web of authority and power.

What are the identitarian dimensions of the quarters' different political positioning in the Uprising? Mezza 86 and Barzeh embody the "us" and "them" division along socio-economic lines that overlap with affiliation or membership in particular confessional groups. Both quarters are on the city's margins in economic, social, and cultural terms. The main distinction 
between the Sunni rural migrants and the Alawi rural migrants has to do with the functionalization of sect as a mechanism in the institution of coercion, and its articulation with the socio-spatial and economic realignments of the populist phase and, later on, with the neoliberal conjuncture. The sectarian divisions revolve around Alawi links with the regime and, on the whole, do not express antagonisms stemming from doctrinal beliefs. Alawis, as a community, are seen to supply the regime with muscle and to reap benefits in return, and the anger directed at Alawis is primarily due to their perceived position as supporters and beneficiaries of the regime. ${ }^{23}$ As observed by Mallon (1994: 1511), when we scrutinize local relations of power, the presumed solidarity and unity of the subaltern dissolves and we are confronted instead with thorny issues of complicity and hierarchy among subaltern communities.

Subalternity in Syria has been differentiated in terms of relations with the regime. Clientelized since their establishment, and embodying the regime's strategies of cultivating and exploiting sectarian divisions, poor quarters such as Mezza 86 have supplied some of the coercive force used against the Uprising. According to local observers, many of the young men from these quarters have now joined the shabiha - the hired strongmen that attack demonstrations on behalf of the regime. It is also among these clientelized sectors that the regime draws supporters for pro-Asad rallies.

\section{Old Damascus and Rural Damascus in the Uprising}

If some of the strongest opposition to the regime has come out of informal quarters such as Barzeh and Qaboun, a number of the historical quarters of Damascus have also been at the forefront of oppositional mobilization and activism. Most notable are Midan and Rukn al-Din, both representative of traditional Sunni Damascene society. Rukn al-Din is also the city's historical Kurdish quarter. Here I will focus on Midan's participation in the Uprising.

As one of the city's historical quarters, Midan has preserved its traditional identity and demographic composition through a period of rapid transformation. Unlike intra-muros quarters such as Shaghour Juwwani and al-Qaymiriyya, which lost many old families to either modern quarters or rural Damascus, Midan retained many of its established and prominent families. It is closely identified with Damascene merchant and manufacturing households that work and trade in the markets of Hamidiyya and Hariqa. By virtue of this association, Midan has preserved a certain degree of continuity

23 This should not be understood to mean that the Alawis, as a community, rule Syria or that the regime has ruled on their behalf. Until the beginning of the Uprising, the regime was based on a historical alliance - consolidated with the crushing of the Islamist insurgency in 1982 - between the Alawi-dominated military elite and the upper-class Sunni merchants. This alliance allowed the latter to safeguard their economic interests and prosper. Even before the Uprising, this alliance was under strain due to the growth of monopoly capitalism associated with the regime's inner circle (see Ismail 2009). 
in the city's urban history. Quarter residents articulate a strong, territorialized identity associated with a conservative lifestyle and long, continuous residence in the quarter. For example, young people from Midan whom I interviewed often invoked a Midani identity to explain cultural practices governing gender interactions.

Historically, the relationship between Midan and the regime has been characterized by autonomy and antagonism. The mercantile and manufacturing economic activities of Midanis have afforded them relative autonomy from the regime. ${ }^{24}$ There is an undercurrent of hostility toward the regime as well, linked to the quarter having been implicated in anti-regime activities connected with the Islamist insurgency in the late 1970s and early 1980s. It was in relation to these activities that the regime first attempted to penetrate Midan. At that time, youth from Midan organized in religious circles centered on a number of mosques and joined the Islamist opposition. Also during that period, the regime implemented plans to transform the quarter's spatial arrangements, most importantly by building a wide road that cut through its middle, splitting what had been contiguous space into sections. This was associated with the construction of modern high-rises on the far extension of the new road, which transformed the built environment characterized, until then, by narrow alleyways and traditional "Arab homes." However, some of the old sections have survived, and these are where most of the demonstrations have taken place. The alleyways and networks of neighborhood association have been hospitable space for protests. Midan activists also organize flash protests in which slogans are shouted decrying the regime and declaring that in Midan it has fallen (andna bil midan saqt al-nizam). These protests are intended to assert a wider opposition presence in the quarter and to garner and demonstrate quarter support for the Uprising.

Activists I interviewed after the Uprising had started pointed out that grievances against the regime extend back to the period of the Islamist opposition, and that many families have had members imprisoned or disappeared. In addition to this history, Midan's central mosques proved fertile ground for the mobilization of youth with their own grievances. Although some activists came from outside Midan, on the whole the protests took root in the quarter and centered on key mosques and their surrounding areas (e.g., al-Hasan, Manjak, al-Daqqaq, and Mansour). To explain the nearly unique ability of Midani residents to mount a sustained campaign of protest we must take into account historical, demographic and spatial factors. The presence of

\footnotetext{
24 I have noted elsewhere that Damascene middle-merchants have shied away from entering into partnerships with newcomers to the city, including regime figures. On the whole, the two main city markets have been closed to outsiders (Ismail 2009). In this respect, we can also speak of societal practices of exclusion in which rural-urban divisions as well as religious and cultural practices are played out to maintain social distinction and differentiation.
} 
long-established families has bolstered the community's ability to guard against internal divisions and maintain a unified position. The Local Coordinating Committee (LCC) of the quarter devised various strategies to contain the regime's informants (known as 'awayniyya), naming them and using familial ties and employment associations to dissuade them from continuing their cooperation with the regime.

In trying to explain the relative quietism of other city quarters, both new and old, activists argued that the influx of new residents and departure of many traditional Damascenes played a part in limiting mobilization. They also noted that the close-knit social networks of adjacent towns have been a factor in their strong participation in the Uprising. Some pointed out that Damascenes travel to satellite towns such as $\mathrm{Mu}$ 'adhamiyya to protest. Beyond these factors, we must also recognize the impact of the extensive presence of security forces in the city's central areas. One document prepared by activists to assess the feasibility of occupying city squares observed that Damascus' main square, Umayyad Square, was fortified from all directions, and that in the immediate vicinity were ten thousand of the Republican Guard (stationed nearby), the Air Force headquarters, the army chief of staff offices, the criminal security headquarters, the political police, and the state security. Central Damascus was viewed as a military garrison that the unarmed protestors could not take on.

As I have already noted, the new towns adjacent to Damascus have been sites of increased resistance to the regime, and I want to highlight briefly their place in the Uprising. A number of these towns - some right on the city's edge and others within a half-hour's drive - have witnessed wide-scale mobilization and intensified protests. For instance, residents of Joubar and Saqba, contiguous towns located in the al-Ghuta al-Sharqiyya, tried to march into the city and occupy Al-Abassiyyin Square in its northeast. One early attempt, in April 2011, saw an estimated thirty thousand protesters mobilized from the two towns. They marched to Abassiyyin Square only to meet security forces who dispersed them with gunfire and live bullets. Abassiyyin Square was attractive to the marchers because there is only one security branch in its vicinity (Air Force intelligence). Also, it is within a 4-10 kilometer radius of the mobilized quarters and districts (al-Tel, Douma, Harasta, Joubar, 'Arbin, Qaboun, Barzeh, Midan, and Rukn al-Din) (from a strategy document posted on the website of the Midan Coordinating Committee of the Revolution, on 1 Aug. 2011).

Relatively distant and newly urbanized agglomerations such as Darayya and Mu'adhamiyya, both located in al-Ghuta al-Gharbiyya, have been at the forefront of weekly and daily protests. It is noteworthy that a substantial proportion of their populations is made up of people originally from Damascus who consider themselves Damascene - the inhabitants refer to themselves as "shuwam" (a term used to evoke indigenous Damascene identity), and alleyways in the newly established neighborhoods have been named "harat al-shuwam." It is worth noting, also, that Damascus has always maintained 
close relationships with these towns since many of the Damascene merchants own agricultural land there and set up workshops linked to their commerce in these rural towns. Moreover, the Damascenes who moved there were seeking more affordable land on which to build homes to accommodate their extended families, thus reproducing features of family living in Old Damascus. The Damascenes preserved their mercantile and artisanal vocations, which integrated well into the existing economic activities of the towns. The Damascus rural hinterland developed areas of economic specialization such as carpentry, and the production of canned and dried foods, and textiles. Many of these enterprises are small workshops with just two to three workers who produce for large merchants in the city. In some cases, these economic activities suffered from economic liberalization policies, which provoked hostility toward the regime among a stratum that has preserved a level of autonomy all along. The close ties that these Damascenes maintained with the Old City were on display during the Uprising - activists from Darayya often traveled to Damascus to mobilize protest in al-Midan and other central city mosques (interview with Darayya activist originally from Old Damascus, May 2011), and Damascenes went to Darayya and Mu'adhamiyya to protest, as well.

The demographic and spatial reconfiguration of Damascus over the last forty years must be considered in analyzing the patterns of mobilization seen there. This reconfiguration is characterized by the emergence of new, informal quarters on the city's periphery; the inscription of sectarian lines of division in the topography; the movement of residents from Old Damascus to the suburbs and to newly urbanized towns in the city's historical rural hinterland; and the influx of migrants into the city and their settlement along lines that reproduce an identitarian politics, in which affiliation with a particular sect is politicized.

\section{The Socio-Spatiality of the Syrian Uprising}

The geography of the Syrian Uprising has raised many questions relating to the social forces that support and oppose the regime. Among these is the question of whether the lines of division are primarily religious/sectarian. I will stress some of the key propositions found in accounts given by Syria analysts and observers and will also raise some questions that future research can help to answer.

Some analysts have advanced the view that the Uprising is primarily Sunni, pointing to its location in predominately Sunni areas and to the relative quiet in cities and governorates with large religious minorities, for example in the governorate of Suwayda with its substantial Druze population (e.g., Rasas 2011; Balanche 2011). This same assessment is also made regarding Christian Syrians, who are less concentrated in any particular governorate but are more likely to be identified with specific city quarters in Damascus, Aleppo, Homs, and Hama, which have seen little if any popular protest. In this connection, one Syrian analyst proposed that religious minorities have taken a stance 
as minorities, while Sunni participation in the Uprising has been modulated along class lines, with upper-class Sunnis either supporting the regime or standing on the sidelines and lower-class Sunnis being heavily involved (Rasas 2011). Although this account may be deduced from the geography of the Uprising, it over-simplifies by giving religion too much weight as an explanatory variable. We need to integrate into our analysis other factors characteristic of the geography of protest.

We have seen that, for Damascus, several factors inform the positioning of various forces in the Uprising: a particular history of quarter establishment and settlement, the quarter residents' relations to government, and regime policies of incorporation and exclusion. At issue is not any presumed primordial attachment to a particular religious community, but instead the regime's political functionalization of sect through the cooptation and clientelization of segments of the Alawi community. One can argue that the regime pursued a policy of "communal corporatism," wherein individuals were incorporated on the basis of group membership and loyalty. For example, the Hafez al-Asad regime helped maintain the tribal structure and hierarchy, and relied on tribal leaders to deliver loyalty and support (see Chatty 2010). ${ }^{25}$ Beyond its use of cooptation and clientelization, the regime also manipulated fears of sectarian division and conflict. These fears were nurtured in part by banishing from the public sphere any discussion of matters of religious identity and affiliation, in the name of the dominant secular ideology. The result was that the sectarian dimension of government institutions was pushed out of public discussion yet remained a focus of hidden tensions and resentments.

In the central quarters of the city of Homs, we find strains similar to those observed in the peripheral quarters of Damascus. That is, quarters with predominately Sunni populations joined the Uprising early on while neighboring quarters with predominantly Alawi populations remained loyal to the regime. From the different accounts of activists and observers, the regime appears to have pursued a policy of sectarian mobilization, with the security forces creating pretexts for conflict between the communities. For example, it is reported that the security forces adopted a deliberate policy of recruiting men from the Alawi quarters to form armed militias (known as shabiha) to attack the quarters participating in the Uprising. The regime's historical policy of recruiting "muscle" from among the Alawis has also added to the sectarian antagonisms in these areas, whereas, before, the two communities had lived side by side for generations. In a context of polarization similar to that in the peripheral quarters of Damascus, the central quarters of Homs aligned on opposite sides, with the pro-regime quarters serving as buffer zones against neighboring quarters.

${ }^{25}$ The regime armed Sunni tribal elements in the north to combat the Islamist opposition in the late 1970s and early 1980s. During the Uprising, allied Sunni clans in Aleppo formed armed militia to crush the protests. 
In his analysis of the geography of the Uprising, Fabrice Balanche (2011) argues that there are two distinct patterns of communally based urban organization. The first is that of "encircled cities," of which Damascus and Hama are examples (i.e., cities where Alawi quarters are on the periphery). The second is the "divided" pattern, exemplified by Homs (Alawi quarters are located in the city's center). This geographic snapshot captures the surface territorial divisions. Balanche emphasizes the spatial proximity of many of the rebellious quarters to "Alawi territories" to posit that the Uprising is Sunni in character and expresses communal struggles. ${ }^{26}$ However, the dynamics at work in all of these spaces have to do with socio-political processes discussed earlier, wherein the regime uses the configuration of urban space to fracture the social body. The inscription of antagonisms in urban space is closely tied to the dynamics of power relations involving subaltern forces and the ruling regimes or cliques. In Damascus, the alignment of Alawi quarters with the regime is founded on their position in the apparatuses of coercion, and their insertion into the urban setting as an extension of the ruling clique. In turn, the mobilization against the regime in quarters like Qaboun and Barzeh is driven by the people's experience of social, economic, and political exclusion. Positionality vis-à-vis the regime, which as a result of specific socio-historical and political processes has intersected with sectarian affiliation, informs polarization and divisions among subaltern forces.

\section{O N L U S ION}

In the urban revolutionary protests in both Egypt and Syria, popular forces rose up against oppressive forms of government experienced in the everyday. In both settings, social strata that had been denied basic civil and social rights mobilized in large numbers with the objective of bringing about a radical change of government. The collective protest actions in both countries share common urban features, namely the participation of people from excluded and peripheral urban spaces. However, when we compare the two cases closely, important differences emerge.

In Cairo, in addition to the occupation of large squares by vast segments of the urban population, an urban battle took place behind the scenes and in the back streets. In the city's new popular quarters and the quarters of the Old City, segments of the population directed their opposition and attacks at police stations. The anger at government was rooted in the quotidian experience

\footnotetext{
${ }^{26}$ Balanche (2011: 450) argues that religious minorities sustain the regime, while the main threat to its survival resides in a "united Sunni Arab community." This construction of the opposition to the regime as driven by Sunni communal solidarity overplays the sectarian factor in accounting for the Uprising. In fact, the Uprising in its civil and peaceful component has articulated a clear antisectarian platform through the statements of the coordinating bodies and the writings of political dissidents. Furthermore, certain segments of the Alawi community, in particular writers and intellectuals, have lent their support to the Uprising.
} 
of interaction with the police at the local level, in urban neighborhoods. The battles in popular quarters were inscribed spatially and recalled a particular history of hostility and opposition to government. Integral to the making of the collective subject - the people/al-sha ' $b$ - and to its assumption of political agency, are the territorialized subjectivities that were enacted in the street warfare.

Patterns of popular participation and opposition to the regime witnessed in Damascus and other cities in Syria have differed significantly from those observed in Cairo. My discussion has emphasized socio-spatial factors that have contributed to the fragmentation of subaltern forces in Syria, most importantly the history of the establishment of new urban quarters associated with the militarization of government. A number of quarters in peripheral areas of Damascus were built to house low-level military recruits and their families, and due to the practices and strategies of recruitment into the military since the 1970s, their populations were predominately if not entirely Alawi. The identification of these quarters with the regime, and particularly with the coercive apparatus, entrenched divisions based on an intersection of religious affiliation and socio-political positionality within the peripheral, marginalized, and excluded urban sectors. The regime has instrumentalized the socio-spatial configurations of the quarters whenever it has been challenged, and this has, in effect, turned segments of subaltern migrant populations into buffers for the regime. These features of urban space in Damascus underscore how important the history and character of urban reconfiguration are in determining the shape and course of popular protest and mobilization during revolutionary periods. In Damascus, social differentiation and divisions among the subaltern forces are built into the spatial and demographic reconfiguration of Damascus over the last forty years.

Both cases highlight aspects of the mutual inscription of the subaltern and the popular. In Cairo, the popular is produced in relations of subordination and exclusion as well as through practices of self-valorization and authentication. Practices of subordination entail the deployment by dominant forces of stigmatizing discourses against popular neighborhoods to justify acts of police violence and dispossession there. In turn, "the people" (al-sha'b), as a collectivity with claims to rights, is mobilized. The contested nature of the "popular" is a constitutive element of subalternity as a positionality in a field of political and social struggle. In this respect, the popular as identity enters into the making of subaltern political agency. As Richard Pithouse cautions, we should not read this political agency as an "automatic expression of culture" (2012). The practices and repertoires of resistance may be invested with cultural symbolism, but they develop within power matrices, and not as the expression of fixed cultural habituations.

The subaltern, as position, does not predetermine the kind of politics subalterns engage in, as demonstrated in the case of Damascus. Differentiated 
subalternity, informed by the Syrian regime's policies of cooptation and exclusion, is manifested in divisions and conflicts among subaltern forces that are articulated in identitarian terms. While we uphold the argument against an essential topography of subaltern urbanism, we must take note of the terms in which subordination and resistance are spatially marked.

\section{REFERENCES}

Abo el-Gheit, Mohamed. 2011. Al-Fuqara awlan ya Awlad al-Kalb. (The poor come first oh progeny of a dog), Gedarea Blog, 17 June. At: http://gedarea.blogspot.co.uk/2011/ 06/normal-0-false-false-false.html (accessed 4 Sept. 2012).

Al-Hay'a al-'Ama lil-Isti'lamat, (General Organization for Information). 2011. Yawmiyyat Thawrat 25 Yanayir (Diary of the 25 January revolution). At: http://www. sis.gov.eg/newvr/arm/25day.pdf (accessed 25 Jan. 2012).

Balanche, Fabrice. 2011. Géographie de la Révolte Syrienne. Outre-Terre 29, 3: 437-58.

Bayat, Asef. 2000. From Dangerous Classes to Class Rebels: Politics of the Urban Subaltern in the Global South. International Sociology 15, 3: 533-57.

Beinin, Joel. 2001. Workers and Peasants in the Modern Middle East. Cambridge: Cambridge University Press.

Beinin, Joel. 2012. The Rise of Egypt's Workers. Carnegie Papers. June. At: http:// carnegieendowment.org/2012/06/28/rise-of-egypt-s-workers/coh8 (accessed 2 Feb. 2013).

Chakrabarty, Dipesh. 1992. Postcoloniality and the Artifice of History: Who Speaks for Indian Pasts? In "Imperial Fantasies and Postcolonial Histories," special issue of Representations 37: 1-26.

Chalcraft, John. 2008. Question: What Are the Fruitful New Directions in Subaltern Studies and How Can Those Working on the Middle East Benefit from Them? International Journal of Middle East Studies 40, 3: 376-78.

Chatty, Dawn. 2010. The Bedouin in Contemporary Syria: The Persistence of Tribal Authority. Middle East Journal 64, 1: 29-49.

Crovitz, L Gordon. 2011. Egypt's Revolution by Social Media. Wall Street Journal, 14 Feb. At: http://online.wsj.com/article/SB1000142405274870378680457613798025 2177072.html (accessed 7 Mar. 2011).

El-Ghobashy, Mona. 2011. The Praxis of the Egyptian Revolution. Middle East Report 258 (Spring): 2-13.

Elshahed, Mohamed. 2012. A Tale of Tower and Shacks. Al-Masry al-Youm, English ed., 12 Aug. At: www.egyptindependent.com/print/1045386 (accessed 31 Aug. 2012).

Escobar, Arturo. 2001. Culture Sits in Places: Reflections on Globalism and Subaltern Strategies of Localisation. Political Geography 20, 1: 139-74.

Ezbawy, Yusry Ahmed. 2012. The Role of Youth's New Protest Movement in the January 25 Revolution. IDS Bulletin 43, 1: 26-36.

Gelvin, James. 1998. Nationalism and Mass Politics in Syria at the Close of Empire. Berkeley: University of California Press.

Ghannam, Farha. 2002. Remaking the Modern: Space, Relocation, and the Politics of Identity in a Global Cairo. Berkeley: University of California Press.

Guha, Ranajit. 1988. On Some Aspects of the Historiography of Colonial India. In Ranajit Guha and Gayatri Chakravorty Spivak, eds., Selected Subaltern Studies. Oxford: Oxford University Press, 37-44.

Hinnebusch, Raymond. 1990. Authoritarian Power and State Formation in Syria: Army, Party, and Peasant. Boulder: Westview Press. 
Hussein, Abdel-Rahman. 2012. Was the Revolution Really Non-Violent? Al-Masry al-Youm, English ed., 24 Jan. At: http://www.egyptindependent.com/node/616836 (accessed 1 Sep. 2012).

Ismail, Salwa. 2000. The Popular Movement Dimensions of Contemporary Militant Islamism: Socio-Spatial Determinants in the Cairo Urban Setting. Comparative Studies in Society and History 42, 2: 263-93.

Ismail, Salwa. 2006. Political Life in Cairo's New Urban Quarters: Encountering the Everyday State. Minneapolis: University of Minnesota Press.

Ismail, Salwa. 2009. Changing Social Structure, Shifting Alliances and Authoritarianism in Syria. In Fred Lawson, ed., Demystifying Syria. London: Saqi Books, 13-28.

Ismail, Salwa. 2011. The Syrian Uprising: Imagining and Performing the Nation. Studies in Ethnicity and Nationalism 11, 3: 538-49.

Ismail, Salwa. 2012. The Egyptian Revolution against the Police. Social Research 79, 2: 435-62.

Izzat, Mahmoud. 2012. Kutayyib Ta'limat al-Thawra: Hal Yahraq “al-Tha'ir al-Haq" Qism al-Shurta?" (Manual of the revolution: does "the true revolutionary" burn the police station?). al-Masry al-Youm, 4 Mar. At: http://www.almasryalyoum.com/ node/694866 (accessed 1 Sept. 2012).

Kandil, Hazem. 2011. Revolt in Egypt. New Left Review 68. At: http://newleftreview. org/?view=2884 (accessed 2 Apr. 2012).

Kandil, Hazem. 2012. Why Did the Egyptian Middle Class March on to Tahrir Square? Mediterranean Politics 17, 2: 197-215.

Khoury, Philip. 1984. Syrian Urban Politics in Transition: The Quarters of Damascus during the French Mandate. International Journal of Middle East Studies 16, 4: $507-40$.

Lal, Vinay. 2001. Subaltern Studies and Its Critics: Debates over Indian History. Theory and History 40, 1: 135-48.

Levinson, Charles and Margaret, Coker. 2011. The Secret Rally that Sparked an Uprising. Wall Street Journal, 11 Feb. At: http://online.wsj.com/article/SB1000142405 2748704132204576135882356532702.html (accessed 1 Sept. 2012).

Luccini, Fabio and Davide Morandini, directors. 2011. Bulaq: Among the Ruins of an Unfinished Revolution. Documentary film (available on video). Access courtesy of the directors.

Mallon, Florencia E. 1994. The Promise and Dilemma of Subaltern Studies: Perspectives from Latin American History. American Historical Review 99, 5: 1491-515.

O'Hanlon, Rosalind and David Washbrook. 1992. After Orientalism: Culture, Criticism, and Politics of the Third World. Comparative Studies in Society and History 34, 1: 141-67.

Pithouse, Richard. 2012. Political Agency in South Africa's Shack Settlements. Paper presented to Conference on Urban Revolutions in the Age of Global Urbanism, Jakarta, Indonesia, 12-16 Mar.

Prakash, Gyan. 1992. Can the Subaltern Ride? A Reply to O'Hanlon and Washbrook. Comparative Studies in Society and History 34, 1: 168-84.

Rasas, Sayyid. 2011. Kharita Ijtima'iyya, Siyyasiyya, Iqtisadiyya lil-Ihtijaj fi Suriyya" (A social, political, and economic map for protests in Syria). Al-Hayat, 30 July. At: http://international.daralhayat.com/internationalarticle/292743 (accessed 15 Aug. 2011).

Roy, Ananya. 2011. Slum Dog Cities: Rethinking Subaltern Urbanism. Journal of Urban and Regional Research 35, 2: 223-38.

Singerman, Diane. 1995. Avenues of Participation: Family, Politics and Networks in Urban Quarters of Cairo. Princeton: Princeton University Press. 
Spivak, Gayatri Chakravorty. 2005. Scattered Speculations on the Subaltern and the Popular. Postcolonial Studies 8, 4: 479-86.

Webber, Sara. 1998. Middle East Studies and Subaltern Studies. Middle East Studies Bulletin 31, 1: 11-16.

Abstract: This paper investigates the role of urban subalterns both as participatory agents in the Arab revolutions and as mediating forces against revolutionary action. It argues that during revolutionary periods the positioning of subalterns as a political force should be understood in relation to their socio-spatial location in the urban political configuration. Looking at the protest movements in Cairo and Damascus, the paper examines the differentiated locations of subaltern actors in each to demonstrate how their positioning in relation to state and government has shaped their engagement in the revolutions. In Cairo, the mobilization of subaltern forces was anchored in spatialized forms of everyday interaction between popular forces and agents of government. These interactions were formative of urban subjectivities that entered into the making of "the people" as the subject of the Revolution. In Damascus, the configuration of the urban space and the Syrian regime's modes of control made it difficult for subaltern forces to mobilize on the same scale as in Cairo or to form a unified opposition. The regime instrumentalized socio-spatial fragmentation among subalterns, in effect turning some segments, as buffers for the regime, against others. In analytical terms, the paper underscores the common conceptual ground between the categories of "urban popular forces" and "urban subalterns." This ground covers their socio-spatial positionality, their bases of action, and the factors shaping their political subjectivities. 